\title{
Gender Quotas for Political Participation and the Case of Georgia
}

\author{
Irina S. Amiantova $₫ \square$, Nikoloz Bitsadze $\mathbb{D}$ \\ Peoples' Friendship University of Russia (RUDN University), Moscow, Russian Federation \\ 凹amiantova_is@rudn.ru
}

\begin{abstract}
The current study focuses on the key elements limiting the political representation of women in the modern world. In order to eliminate discrimination, some countries introduce gender quotas for political participation. Studying the legal framework of modern Georgia shows that, despite the existing common legal basis for the equality of women and men, the reality in political life is different. The lack of effective quota mechanisms significantly weakens the realization of women's civil and political rights. Stereotypical attitudes and perceptions about the role of women in society are the main barriers to recruiting in the political and administrative deployment. Considering the gender aspect of political representation as a complex problem necessitated a systematic approach. The historical and comparative method was used to study the evolution of gender equality. A separate group of methods used in the article was made up of the political and legal analysis of empirical database national statistics. The article shows how the Georgian Parliament affects the position of women in politics by introducing mandatory quotas for national and local government elections, increasing the likelihood of women running, being elected and appointed.
\end{abstract}

Keywords: Georgia, gender quotas, political representation, stereotypes, government

For citation: Amiantova, I.S., \& Bitsadze, N. (2022). Gender quotas for political participation and the case of Georgia. RUDN Journal of Political Science, 24(1), 136-147. https://doi.org/10.22363/23131438-2022-24-1-136-147

\section{Гендерное квотирование политического участия на примере Грузии}

\author{
И.С. Амиантова $\mathbb{\square}$, Н. Бицадзе $\mathbb{D}$ \\ Российский университет дружбы народов, Москва, Российская Федерация \\ 凹amiantova_is@rudn.ru
}

\begin{abstract}
Аннотация. В фокусе внимания - исследование ключевых факторов, ограничивающих политическое представительство женщин в современном мире. Залогом защиты от дискриминации служит успешное проведение гендерного квотирования политического участия. Изучение законодательной базы современной Грузии показало, что, несмотря на наличие общей

(C) Amiantova I.S., Bitsadze N., 2022

(i) This work is licensed under a Creative Commons Attribution 4.0 International License https://creativecommons.org/licenses/by/4.0/
\end{abstract}


правовой основы для равноправия женщин и мужчин, реальность в политической жизни иная. Отсутствие эффективных механизмов квотирования заметно ослабляет реализацию гражданских и политических прав женщин. Стереотипные взгляды и представления о роли женщин в обществе служат основными барьерами рекрутирования в политико-административном направлении. Рассмотрение гендерного аспекта политического представительства как комплексной проблемы обусловило необходимость применения системного подхода. При исследовании эволюции гендерного равенства использовался исторический и сравнительный метод. Отдельную группу используемых в статье методов составил политико-правовой анализ эмпирических данных национальной статистики. В статье показано, как законодательная власть Грузии, вводя обязательные квоты для национальных и местных правительственных структур, влияет на положение женщин в политике, увеличивая вероятность того, что они будут баллотироваться, избираться и назначаться.

Ключевые слова: Грузия, гендерные квоты, политическое представительство, стереотипы, власть

Для цитирования: Amiantova I.S., Bitsadze N. Gender quotas for political participation and the case of Georgia // Вестник Российского университета дружбы народов. Серия: Политология. 2022. T. 24 № 1. C. 136-147. https://doi.org/10.22363/2313-1438-2022-24-1-136-147

\section{Introduction}

Common development theory begins with the hypothesis that traditional society is characterized by sharply differentiated gender roles that affect both women and men in society. The teaching of the various demographic, sociological, anthropological, and social database reveals that gender roles change with the modernization of society [Reyes 2001].

Today, when discussing the importance of women's political representation, we can rely on a list of main arguments. In terms of fairness, women make up half of the population, so they have the right, therefore, to hold half of the representation. The experience-based argument says that women have different experiences, both biologically and socially constructed, the comprehension of which is important. According to the argument concerning interests, women and men have opposite interests, and therefore these interests should not be represented only by men. According to the symbolic argument, the activities of a female politician serve as some kind of a role model and attract women to engage in politics, regardless of which party or political force the woman represents: it is still a raw theory very much dependent on unique social characteristics. According to the critical mass argument, women develop a sense of solidarity and want to be representative of other women only after they have reached a certain level of appreciation. According to the democratic argument, equal representation of women and men increases the level of democratization of governance in both transitional and consolidated democracies. In addition, seems that 9 out of 12 countries, where women hold more than $33 \%$ of parliamentary seats, are characterized by a high level of development with more girls having access to education, low illiteracy, relatively higher economic development, etc. ${ }^{1}$

\footnotetext{
${ }^{1}$ Shreeves, R., \& Hahnkamper-Vandenbulcke, N. (2021). Gender mainstreaming in the European Parliament. European Parliamentary Research Service, PE 694.216, 18-22.
} 
The current situation, when the representation of women in politics is quite small, is due to a number of factors. Women's involvement, participation and access to formal political power are linked to several structural and functional barriers that vary from country to country. According to many authors, the absence of women in the political arena is caused by such obstacles as political, socio-economic, ideological and psychological barriers [Ara 2019]. Women are under-represented in political institutions, which means that they are less involved in decision-making processes that shape public opinion. That is why economists and political scientists are increasingly interested in the causes of gender inequality in terms of women's participation in politics [Hernes 2018].

Importantly, despite the great variation between countries, the issue of gender inequality in terms of women's participation in politics is relevant all over the world, including in countries with high levels of social and economic development. For example, Sweden, which has high rates of female participation in various state institutions (currently $47.5 \%$ of members of parliament, $54.5 \%$ of ministers and $43 \%$ of members of municipal councils), has never had a female prime minister (Magdalena Andersson resigned hours after appointment) and only one-third of mayors are female. Eastern European and Central Asian countries have been able to eliminate $15 \%$ of the gender gap in women's political participation, which, according to the World Economic Forum, is the lowest rate of progress among the components of the Gender Equality Index. ${ }^{2}$

In a general context, three main reasons for this situation are most often mentioned: (1) women do not want to become politicians, (2) voter bias, and (3) party bias. Large-scale surveys have found that women whose professional and economic status promotes them as potential political candidates are less likely than men to have the ambition to hold leading political positions [Barnes 2019]. The main reason for the gender gap between ambitions seems to be that women (a) have less support than men, participate in elections, and (b) are less likely to believe that men are more qualified to hold such positions.

Such an outcome may also be influenced by the fact that women avoid competition, and the political selection process is indeed highly competitive. Scientists conducted experiments in which people were introduced to the competitive nature of politics: the studies found that as a result, women's interest in politics declined, while this information had no significant effect on men [Shames, Wise 2017].

Women's desire to build a successful political career can also be influenced by family and kinship relationships [Baturo, Gray 2018]. A recent paper shows that in Sweden, the likelihood of divorcing a partner increases significantly when female politicians reach the rank of a mayor (which is the highest position in municipal politics), while this is not the case for male politicians.

2 Global Gender Gap Report 2020. World Economic Forum. 2019, 37-44. URL: https://www.weforum.org/reports/gender-gap-2020-report-100-years-pay-equality (accessed: 03.01.2022). 


\section{Political Process Regulatory Gender Quotas}

There are different approaches to the issue of removing barriers to women's low political participation. For example, in Georgia, the so-called low political participation of women is ruled out by many NGOs that are planning various training programs to equip women participants with the knowledge, skills, and human connections needed for a political career. ${ }^{3}$ Gender-based party-list quotas are the most frequently used form of intervention to increase women's low political participation: the effects of this intervention are well studied. Given their design and the context in which they are used, quotas are more or less successful in empowering and representing the interests of women. As these quotas have some nuances, countries or regions planning to introduce them should design the intervention with experts on the issue and shouldn't regard quotas as a panacea.

Today, women make up about $25 \%$ of the world's parliamentarians. Given this low rate, it is imperative that states take more effective steps to achieve gender balance. Mandatory electoral quotas are considered to be one of the mechanisms for ensuring women's political representation. ${ }^{4}$ This political action has a crucial, long-term and sustainable positive impact on increasing the number of female candidates and women elected. ${ }^{5}$ Today it is used in more than 100 countries around the world. ${ }^{6}$ The quotas allow to end the low representation of women in leading positions and make women holding managerial positions part of daily practice in the political, economic and academic spheres. This tool can only change the decision-making practices of men and provide for the appointment of qualified women to relevant positions [Profeta 2020]. It is an effective mechanism for the rapid elimination of inequality. Contrary to this view, the "growing rate policy" believes that the development process is gradual and natural, consequently, gender equality itself will be gradually established, whereas political intervention is considered unnecessary [Profeta 2020].

There are 3 types of quotas: ${ }^{7}$

- Voluntary quota (same as party quota) - when parties voluntarily include a gender quota in the lists.

- Mandatory quota (same as the legislative quota) - when the constitution or law obliges parties to observe gender balance when compiling party lists.

\footnotetext{
${ }^{3}$ Saikia, M., \& Saikia, P. (2019). Economic Empowerment of Women through NGO: A Case Study (p. 91). Dera Natung Government College Research Journal. URL: https://intown-solutions.com/ dngc/wp-content/uploads/2019/09/8-Economic-Empowerment-of-Women-through-NGO.pdf (accessed: 03.01.2022).

${ }^{4}$ Proportion of seats held by women in national parliaments (\%). The World Bank Data. URL: https://data.worldbank.org/indicator/SG.GEN.PARL.ZS. (accessed: 27.12.2021).

${ }^{5}$ Women in National Governments Around the Globe: Fact Sheet. (2021). Congressional Research Service (pp. 1-16); R45483.

${ }^{6}$ Policies and Practices to Promote Women in Leadership Roles in the Private Sector. (2020). Report prepared by the OECD for the G20 EMPOWER Alliance (pp. 13-31).

${ }^{7}$ Dahlerup, D., Hilal, Z., Kalandadze, N., \& Kandawasvika-Nhundu, R. (2013). Atlas of Electoral Gender Quotas. International IDEA, (SE-103 34), 16-34. URL: https://www.idea.int/sites/default/ files/publications/atlas-of-electoral-gender-quotas.pdf (accessed: 16.01.2022).
} 
- Quota of reserved seats - in some countries, a certain number of parliamentary seats are reserved for women, and these seats cannot be disputed by men. This method is often used in Africa and Southeast Asia [Ballington 2014].

Mandatory and voluntary quotas may include any of the three stages of candidate selection: postgraduates, candidates, and elected representatives. Two factors are important for improving the representation of women in politics: (1) the electoral system; and (2) the willingness of the political parties to change the current unfavorable situation [Mlambo, Kapingura 2019]. It should be noted that there are different models of quotas. If the institutional context is not considered, quotas can only have a symbolic meaning and cannot have a real impact on women's participation. For example, quotas operate differently under different electoral systems. They easily adapt to the proportional rule (PR) when votes are converted into mandates. Most countries with high female participation have this type of electoral system: this figure is about twice that of the states that use majoritarianism [Belschner, de Paredes 2021].

Adhering to the redistribution of seats in the electoral list is extremely important for more women being elected through quotas. In both mandatory and party quotas provisions should include rules on the placement of candidates on the electoral roll ("passing seats") so that female candidates do not end up at the bottom of the list. A quota system that does not address this issue may not eliminate the problem of women's representation at all [Hessami, Lopes da Fonseca 2020]. Another important issue is legal sanctions for non-compliance with mandatory quota requirements. Studies show the most effective way is the refusal of election commissions to register voter lists that do not meet the quota requirements established by the law.

\section{Barriers Hindering Women to Take Part in the Political Process of Modern Georgia}

10 out of $28 \mathrm{EU}$ countries use mandatory quotas for the highest legislative bodies: Belgium, Spain, Slovenia, Poland, Croatia, Greece, Ireland, France, Italy and Portugal. The first 6 of these also use the Unified Proportional Electoral System (List PR). Party quotas are valid in the following 13 EU member states: UK, Sweden, Slovakia, Romania, Netherlands, Malta, Lithuania, Germany, Czech Republic, Austria, Luxembourg, Cyprus, Hungary. Since party quotas are voluntary, the focus should be made on individual parties to study its effect. ${ }^{8}$

There are no quotas in 5 EU member states: Estonia, Denmark, Finland, Latvia, Bulgaria. Their data in terms of women's representation are as follows: Finland 47\% (2019 elections), Denmark 39.1\% (2019), Latvia 30.0\% (2020), Bulgaria 26.6\% (2020), Estonia 28.7\% (2020). In Denmark and Finland, even without quotas, women have historically been highly represented in politics. However, the

\footnotetext{
${ }^{8}$ European Women on Boards Gender Diversity Index. (2020). Rights, Equality and Citizenship Programme of the European Union (pp. 12-24).
} 
situation in the new democracies (Latvia, Bulgaria and Estonia) is substantially problematic in this regard. ${ }^{9}$

According to the World Economic Forum Gender Equality Index, Georgia ranks 60th out of 153 countries in terms of women's participation in politics ( 0.245 points out of a possible maximum of 1 point). Although Georgia's rate slightly exceeds the average for Eastern Europe and Central Asia, it is positioned right in the regional middle with 0.732 . Among the subcomponents of the Gender Equality Index, women have the lowest rate of participation in politics (see Figure 1). Between post-Soviet countries and neighbouring states, Georgia has the lowest percentage of women represented in the Parliament (Georgia - 14.2\%, Armenia - 23.5\%, Azerbaijan - 17.4\%, Inter-Parliamentary Union, 2020). However, significant progress is observed compared to the 1990 figure (when the percentage of women was $6.4 \%$; see Figure 2).
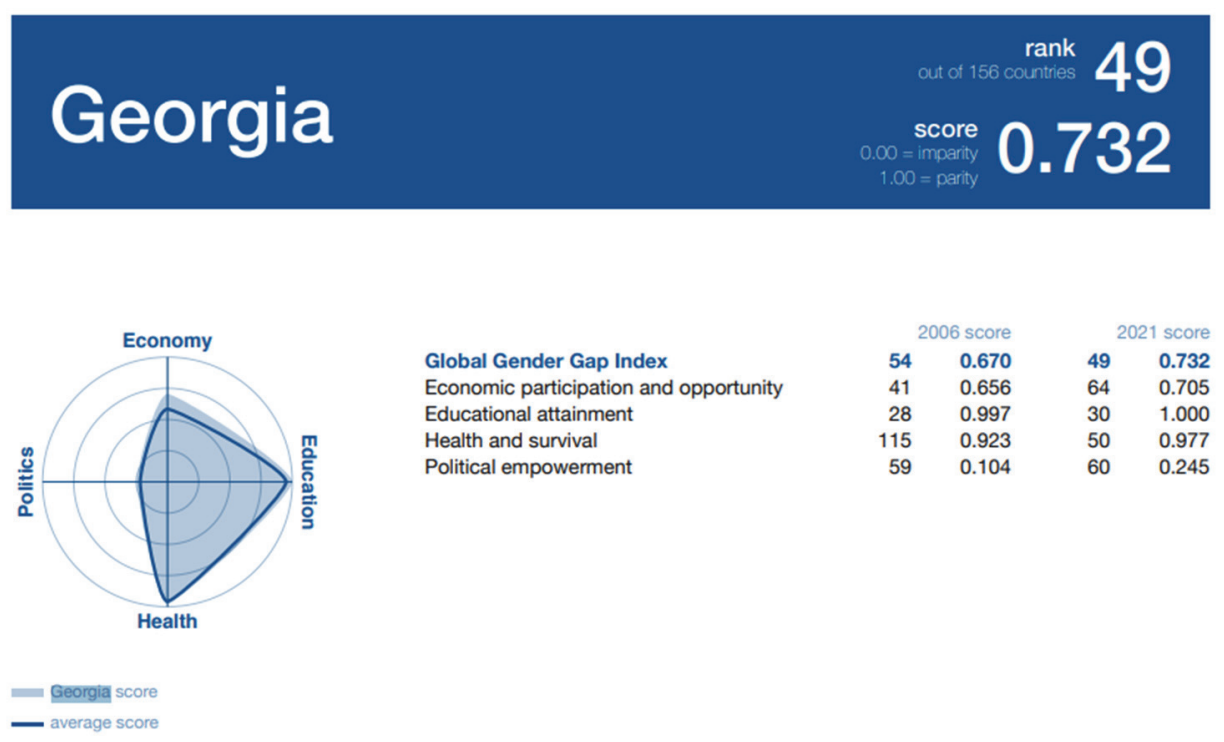

Fig. 1. Georgia in Global Gender Index Source: Global Gender Gap Report $2021^{10}$

The last parliamentary elections in Georgia were held on October 31, 2020, and the second round of elections ended on November 21, 2020. One of the most important changes in this election was the introduction of a gender quota in party lists. The quota required that at least one in four candidates on the party list were women. This requirement did not apply to majoritarian candidates in singlemember constituencies ( 30 out of 150 seats). From the 6882 candidates on the proportional party lists, $44.3 \%$ (3049) were women, while only $21.75 \%$ (107 out of 492 candidates) were women among the majoritarian candidates. ${ }^{11}$

\footnotetext{
${ }^{9}$ Report on gender equality in the EU 2021. (2021). European Union (p. 39).

${ }^{10}$ Global Gender Gap Report 2021. (2021). World Economic Forum (pp. 197-198).

${ }^{11}$ International Election Observation Mission for Georgia - Parliamentary Elections. (2020). The OSCE Parliamentary Assembly (pp. 10-20). (In Georgian).
} 


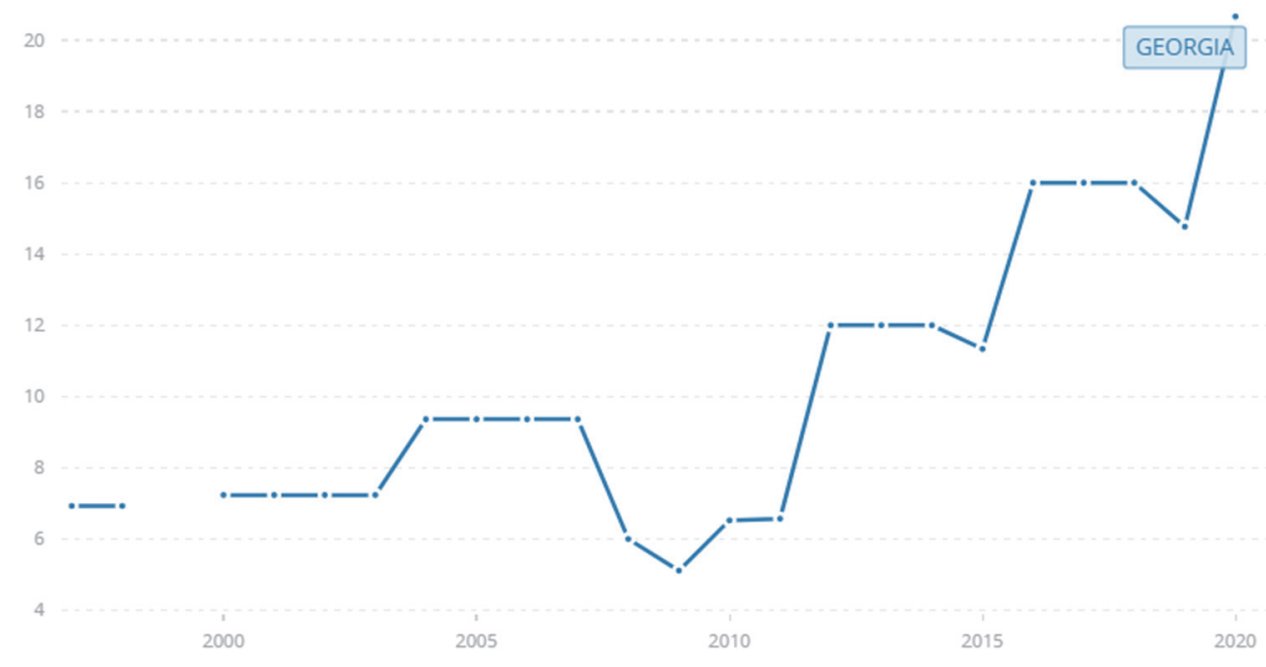

Fig. 2. Proportion of seats held by women in national parliaments in Georgia (2000-2020), \% Source: World Bank Data ${ }^{12}$

In total, 30 women were elected to parliament (20\%). Although this number is higher than the previous election rate (16\% without gender quota), it still falls short of the target of $25 \%$ meant by the quota. It should be noted that 29 women parliamentarians were elected through party lists, and one - by majoritarian rule. The election results indicate that almost all party lists met the gender quota requirements for leading candidates. $44.3 \%$ of the party-list candidates were women, although they accounted for only $24.2 \%$ of the party-list candidates who made it to the parliament. This suggests that women were more likely to be represented at the bottom of party lists (where the chances of being elected to the parliament are lower). This once again indicates that men are still dominant in Georgian politics. ${ }^{13}$ The package, approved by the Parliament of Georgia that calls for amendments to the electoral code, including mandatory gender quotas, aimed at gradually increasing the representation of women in parliament. ${ }^{14}$

The situation of women's representation in local self-government bodies outside Tbilisi is worse than at the national level. Although small positive dynamics have been observed in recent years, according to the 2017 local elections, the average share of women in local councils was only $13.5 \%$ (it should be noted that this number is higher in Tbilisi - 20\%). ${ }^{15}$

\footnotetext{
${ }^{12}$ Proportion of seats held by women in national parliaments (\%). (2021). Inter-Parliamentary Union (IPU). URL: https://data.worldbank.org/indicator/SG.GEN.PARL.ZS?locations=GE (accessed: 03.01.2022).

${ }^{13}$ FROGEE Policy Conclusions from Georgia. (2021). ISET - International School of Economics at TSU (pp. 9-13). (In Georgian).

${ }^{14}$ The future parliament of Georgia: with or without increased representation of women? (2021). UNDP Europe and Central Asia. URL: https://equalfuture.eurasia.undp.org. (accessed: 03.01.2022). (In Georgian).

${ }^{15}$ Alivizatos, N., Frendo, M., Pabel, K., \& Karagiannidou, E. (2021). Georgia urgent joint opinion on revised draft amendments to the election code. European Commission for Democracy Through
} 
The 2021 local self-governance elections were held according to different rules from the previous elections: one of the changes concerned the introduction of gender quotas in the elections for the city councils - parties were obliged to include at least one female candidate in the top three candidates in the proportional list. The law was passed by the parliament after a bill was introduced that required every second candidate on the Sakrebulo's (Local Government) proportional lists to be a woman. The rule did not apply to the 2017 local government elections, although there was an incentive to allow parties whose every third candidate on the list would be of the opposite sex to receive additional funding. Nevertheless, if we analyze the results of the 2017 elections, only 10 out of 50 members of the Tbilisi City Council were women, and among the 25 members included in the proportional list, only 4 were women. ${ }^{16}$

In addition to gender quotas, another change concerns the number of majoritarian constituencies. If until now 25 members were elected in the Tbilisi Sakrebulo by proportional representation and 25 by the majoritarian system, Tbilisi was represented by 10 majoritarian constituencies in the 2021 local self-governance elections. The number of candidates running on the proportional list did increase and the City Council was staffed in the proportion of 40/10. ${ }^{17}$

Another challenge to gender equality in Georgia is the inappropriate social environment, which does not allow women to overcome a certain barrier of financial well-being in order to participate in political activities. Over the past few years, poverty in Georgia has declined significantly in both urban and rural areas. Since 2010, poverty at the national level in Georgia has decreased from $37.3 \%$ to $19.5 \%$ in 2019 . Generally speaking, it should be noted that the greatest decline in poverty was recorded in rural areas. Between 2010 and 2019, rural poverty fell by almost 20 percentage points, from $43.3 \%$ to $23.7 \%$. Meanwhile, the poverty rate in urban areas also fell from $32.7 \%$ to $16.4 \%$. During the period from 2018 to 2019 , there was a decrease in the national poverty level, but at the same time, poverty increased slightly among rural households (see Figure 3).

It is possible to talk about the dependence of the well-being of women on marital status, which also represents a barrier to the solvency of women in political life. Married women are most likely to suffer from poverty, and divorced women are a very vulnerable group, they are on average ten percent poorer than married women. Unequal status in family relations and the impossibility of independent economic activity jeopardize women's ability to participate in politics. Moreover, divorced women often become economically vulnerable, as they were participants in economically unequal marriages (see Figure 4).

\footnotetext{
Law (Venice Commission) (pp. 6-12). URL: https://www.venice.coe.int/webforms/documents/ default.aspx?pdffile=CDL-PI(2021)011-e (accessed: 16.01.2022)

${ }^{16}$ Elections and Democracy. (2021). Election Magazine № 5. Supreme election commotion. URL: $\mathrm{https}$ ://rm.coe.int/ready-for-printing-electoral-journal-5th-edition/1680a32082 (accessed: 03.01.2022). (In Georgian).

${ }^{17}$ Organic Law of Georgia Local Self-Government Code. Official Tbilisi City Council Website. (2021). URL: http://www.tbsakrebulo.gov.ge/uploads/reglamenti/kanoni_adgilobrivi.pdf (accessed: 03.01.2022). (In Georgian).
} 


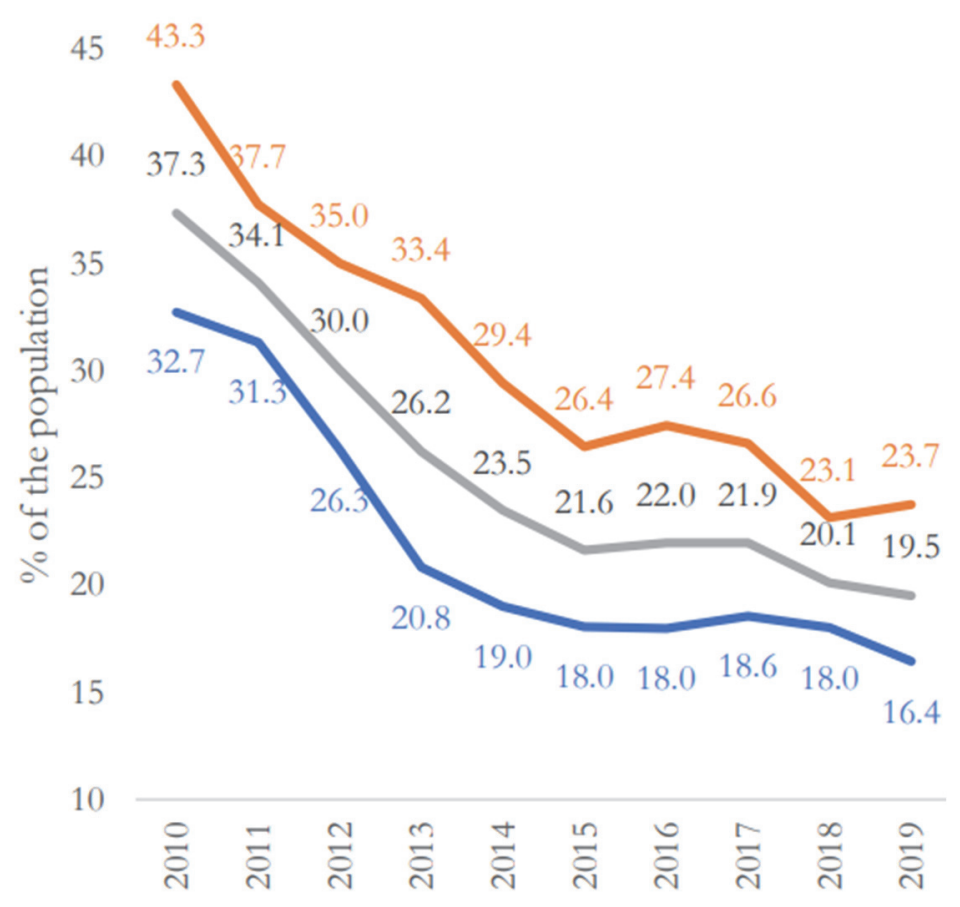

Fig. 3. Georgia poverty rate 2010-2019

Source: National statistics of Georgia ${ }^{18}$

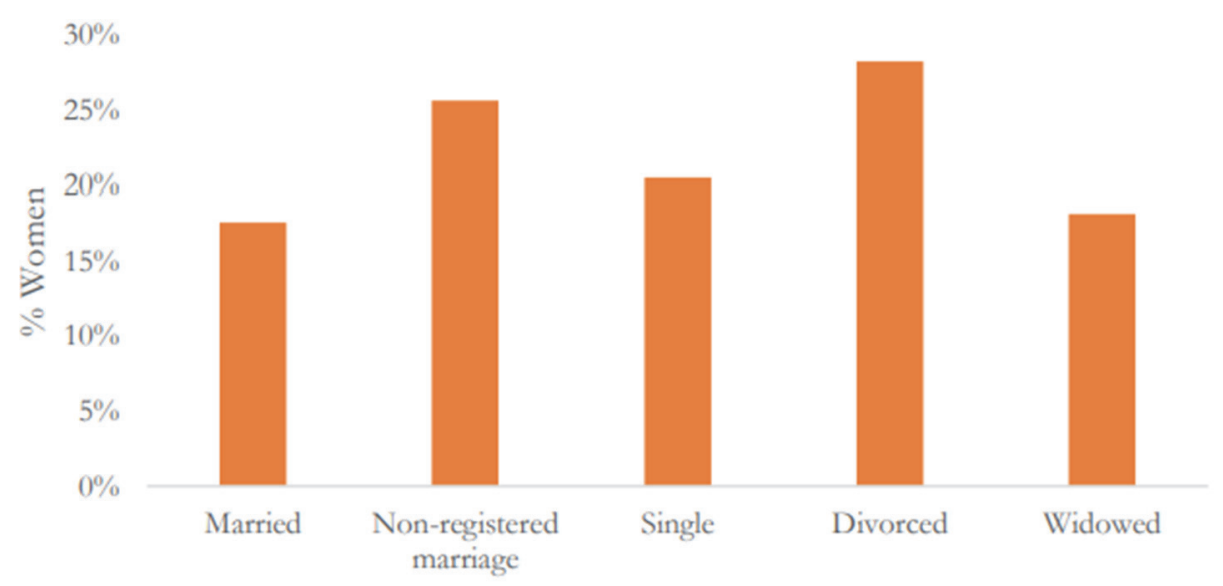

Fig. 4. Poverty incidence by marital status of women, 2020

Source: The World Bank. Country Gender Assessment Georgia ${ }^{19}$

18 National statistics office of Georgia. Share of population under absolute poverty line. URL: https://www.geostat.ge/en/modules/categories/192/living-conditions (accessed: 03.01.2022). (In Georgian).

19 The World Bank. Country Gender Assessment Georgia. 2021. URL: https://documents1.worldbank.org/curated/en/407151616738297662/pdf/Georgia-Country-GenderAssessment.pdf (accessed: 16.01.2022). Note: Poverty defined by the national absolute poverty line. Restricted to women 15 years and older. 


\section{Conclusion}

The difference between the participation rates of women and men in Georgian politics can be explained by the fact that they have different interests and desire to participate in politics. The most important factors influencing the low participation of women in Georgian politics are the attitude of women towards the election campaign and the political environment, family traditions, the perception of gender roles in the society. This opinion is supported by the results of focus groups conducted with women living in different parts of Georgia [Serpe 2018]. According to the survey, most women think that politics is a "dirty" business. Women are also concerned that the campaign will negatively affect their children and families. According to the traditional distribution of family affairs, the burden of family responsibilities falls mainly on women, which prevents women from engaging in politics. In Georgia, women have a disproportionately high share of household chores compared to men, while women who work full-time bear the double burden of family and work responsibilities. According to the latest survey of the United Nations Population Fund, ${ }^{20}$ domestic activities in Georgia, such as cleaning, cooking or laundry, are the duty of women for $80 \%$ of respondents. $49 \%$ of respondents said that childcare activities in the family are the prerogative of women, while $43 \%$ said that the above cases are divided between women and men in the family.

Inadequate representation of women in Georgian politics is also conditioned by the factors of the "demand" side: the society's expectations towards the candidates are incompatible with their gender expectations. This finding is particularly relevant to Georgia, where traditional views on how women should behave differ significantly from public perceptions of how leaders should behave. This attitude has changed over time. According to a United Nations Development Program survey, by $2020,60 \%$ of respondents supported the involvement of women in political life. This figure is 10 percent higher than the 2013 figure $(50 \%)$. The driving force behind this change is a shift in public attitudes towards women's participation in politics, especially among Georgian women. In $2020,72 \%$ of women thought that involving women in politics would be beneficial for the country, up from $56 \%$ in 2013 . The percentage distribution of respondents did not change in the case of men (45\% in 2020 and $43 \%$ in 2013). At the same time, in $2020,37 \%$ of female respondents and $62 \%$ of male respondents agreed with the statement that men are better political leaders than women when in 2013 these figures were $56 \%$ and $69 \%$, respectively. Moreover, by $2020,42 \%$ of women and $63 \%$ of men believed that politics is a man's business. In $2013,56 \%$ of women and $77 \%$ of men agreed with this opinion. This change shows that over the last 8 years,

\footnotetext{
${ }^{20}$ United Nations Population Fund Country programme document for Georgia. (2020). Executive Board of the United Nations Development Programme, the United Nations Population Fund and the United Nations Office for Project Services; DP/FPA/CPD/GEO/4 (p. 10).
} 
Georgians' perceptions and attitudes towards women's social inclusion have significantly improved. ${ }^{21}$

Historically established gender stereotypes that contribute to the unequal distribution of unpaid domestic work in Georgian families are a central barrier to women's increased political participation. Thus, it is important to make policy changes related to the burden of unpaid domestic work: for example, improved access to quality child and elderly care services may significantly reduce the burden of unpaid domestic work on women. At the same time, encouraging men to take maternity leave may play a key role in breaking down gender stereotypes.

Received / Поступила в редакцию: 23.09.2021

Revised / Доработана после рецензирования: 20.10.2021 Accepted / Принята к публикации: 15.11.2021

\section{References}

Ara, F. (2019). Barriers to the political participation of women: A global perspective. Society \& Change, 13(4), 7-22.

Ballington, J. (2014). The Implementation of Quotas: African Experiences Quota Report Series. In J. Ballington (Ed.), International Idea.

Barnes, T., \& Beaulieu, E. (2019). Women politicians, institutions, and perceptions of corruption. Comparative Political Studies, 52(1), 134-167.

Baturo, A., \& Gray, J. (2018). When do family ties matter? The duration of female suffrage and women's path to high political office. Political Research Quarterly, 71(3), 695-709.

Belschner, J., \& de Paredes, M. (2021). Hierarchies of representation: The re-distributive effects of gender and youth quotas, Representation Journal of Representative Democracy, 57(1), 1-20. http://doi.org/10.1080/00344893.2020.1778510

Hernes, H. (2018). Women and the welfare state: the transition from private to public dependence. In A.S. Sassoon (Ed.), Women and the State (pp. 77-92). London, Routledge.

Hessami, Z., \& Lopes da Fonseca, M. (2020). Female Political Representation and Substantive Effects on Policies: A Literature Review. IZA - Institute of Labor Economics (IZA DP No. 13125), 4-13.

Mlambo, C., \& Kapingura, F. (2019). Factors influencing women political participation: The case of the SADC region. Cogent Social Sciences, 5(1), 28-41. https://doi.org/10.1080/23311886.2019.1681048

Profeta, P. (2020). Gender Equality and Public Policy: Measuring Progress in Europe. Cambridge University Press. https://doi.org/10.1017/9781108525886

Reyes, G. (2001). Four main theories of development: modernization, dependency, word-system, and globalization. Nómadas. Revista Crítica de Ciencias Sociales y Jurídicas, 4(2), 109-124.

Serpe, L. (2018). Focus Group Findings on Perceptions of Women in Georgian Politics - An Assessment of Perceptions of Women as Political Candidates and Elected Officials. International Foundation for Electoral Systems. Statistics Sweden.

Shames, S., \& Wise, T. (2017). Gender, diversity, and methods in political science: A theory of selection and survival biases. PS: Political Science \& Politics, 50(3), 811-823.

${ }^{21}$ Men, women, and Gender relations In Georgia: Public perceptions and attitudes. (2020). UN Joint Programme for Gender Equality funded by the Government of Sweden. URL: https://www.ge.undp.org/content/georgia/en/home/library/democratic_governance/gender-surveyreport.html (accessed: 03.01.2022). 


\title{
Сведения об авторах:
}

Амиантова Ирина Сергеевна - кандидат политических наук, доцент кафедры политического анализа и управления РУДН (e-mail: amiantova_is@rudn.ru) (ORCID: 0000-0003-1543-0815)

Бицадзе Николоз - аспирант кафедры политического анализа и управления РУДН (e-mail: 1042208033@pfur.ru) (ORCID: 0000-0001-6567-7184)

\begin{abstract}
About the authors:
Irina S. Amiantova - PhD, Associate Professor at the Department of Political Analysis and Management, Peoples' Friendship University of Russia (e-mail: amiantova_is@rudn.ru) (ORCID: 0000-0003-1543-0815)
\end{abstract}

Bitsadze Nikoloz - postgraduate at the Department of Political Analysis and Management Peoples' Friendship University of Russia (e-mail: 1042208033@pfur.ru) (ORCID: 0000-0001-6567-7184) 